\title{
EU antidiscrimination law and duty of care: fellows in the regulation of MNEs' business relationships
}

\section{Silvia Borelli}

\section{Q OpenEdition}

1 Journals

Electronic version

URL: https://journals.openedition.org/rdctss/1735

DOI: $10.4000 /$ rdctss. 1735

ISSN: 2262-9815

Publisher

Centre de droit comparé du travail et de la sécurité sociale

Printed version

Date of publication: 1 December 2018

Number of pages: $30-43$

ISSN: $2117-4350$

\section{Electronic reference}

Silvia Borelli, "EU antidiscrimination law and duty of care: fellows in the regulation of MNEs' business relationships", Revue de droit comparé du travail et de la sécurité sociale [Online], 4 | 2018, Online since 01 November 2021, connection on 15 November 2021. URL: http://journals.openedition.org/rdctss/ 1735 ; DOl: https://doi.org/10.4000/rdctss. 1735

\section{(c) (†) $९$}

Revue de droit comparé du travail et de la sécurité sociale est mise à disposition selon les termes de la Licence Creative Commons Attribution - Pas d'Utilisation Commerciale - Pas de Modification 4.0 International. 


\title{
EU ANTIDISCRIMINATION LAW AND DUTY OF CARE: FELLOWS IN THE REGULATION OF MNES' BUSINESS RELATIONSHIPS*
}

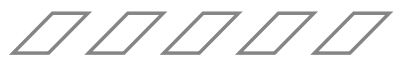

\begin{abstract}
The principles of non-discrimination are binding rules that forbid treating an individual or a group characterised by one or more factors listed by antidiscrimination law in a way that produces or can produce a disadvantage. Discrimination is normally ascribed to the person who has exerted the power that has produced or can produce the discriminatory effect. However, a person can be liable for discrimination as well when she/he has illegally tolerated an act of discrimination. This is the case when a person has a duty to prevent discrimination to happen. The sources of the duty to prevent discrimination to happen can be enshrined in the duty of care of one company over a different one. Based on this conceptual framework, the paper discusses the possibility to sue a European company (i.e. a company that has its headquarters or a unit in Europe) for acts of discrimination caused by its subsidiaries, suppliers or subcontractors inside or outside the EU territory. Distinguishing among national, European and international sources, the author demonstrates how the interconnection between EU Antidiscrimination Law and the duty of care can be helpful to enforce a non-legally binding duty of care and to guarantee to victims effective remedies.
\end{abstract}

KEYWORDS : Antidiscrimination Law, Duty of Care, Liability.

\section{RÉSUMÉ}

Les principes de non-discrimination sont des règles contraignantes qui interdisent de traiter un individu ou un groupe caractérisé par un ou plusieurs facteurs énumérés par la loi anti-discrimination d'une manière qui produit ou peut produire un désavantage. La discrimination est normalement imputée à la personne qui exerce le pouvoir qui a produit ou peut produire une discrimination. Cependant, une personne peut également être responsable de discriminations lorsqu'elle a toléré illégalement un tel acte. C'est le cas lorsqu'une personne a le devoir d'empêcher les discriminations de se produire. Les sources de l'obligation de prévenir les discriminations peuvent être inscrites dans le devoir de diligence d'une entreprise vis-à-vis d'une autre. A partir de là, cet article discute de la possibilité de poursuivre une société européenne (c'est-à-dire une société ayant son siège ou un établissement en Europe) pour des actes de discrimination commis par ses filiales, ses fournisseurs ou ses sous-traitants sur le territoire de l'UE ou hors de celui-ci. En analysant les différentes sources nationales, européennes et internationales, l'auteur montre comment l'interconnexion entre la législation anti-discrimination de I'UE et le devoir de diligence peut être utile pour faire respecter un devoir de diligence juridiquement non contraignant et pour garantir aux victimes des recours efficaces.

MOTS CLÉS : Législation anti-discrimination, devoir de diligence, responsabilité.

*A first version of this paper was presented during the Labour Law Research Network (LLRN) Conference, Toronto, 25-27 June 2017. The author thanks Isabelle Daugareilh and the other participants to her conference's session for their comments. 
he principles of non-discrimination are binding rules that forbid treating an individual or a group characterised by one or more factors listed by antidiscrimination law in a way that produces or can produce a disadvantage. In dealing with an alleged case of discrimination, the court has to verify a) whether a provision, criterion or practice has produced or can produce a disparate impact and b) whether the unequal treatment is objectively justified by a legitimate aim, and if the means of achieving that aim are appropriate and necessary (in the case of direct discrimination, the judge should just verify whether one of the exceptions laid down by antidiscrimination law applies). A provision, criterion or practice can be considered as a form of exercise of power, no matter whether it is a private or public power, legal or factual power. As a result, through the principles of non-discrimination, the judge can examine any form of exercise of power in relation to the effects that it can produce or has produced 1.

EU antidiscrimination directives do notstate who should be held liable for discrimination: whoever exerts a power in the scope of the directives is required to respect the prohibition of discrimination established therein. Consequently, the actor discriminating against an employee or a group of employees is not necessary their employer ${ }^{2}$.

Discrimination is normally ascribed to the person who has exerted the power that has produced or can produce the discriminatory effect. However, EU antidiscrimination law does not provide that only the person (natural or juridical) who has acted in a discriminatory way is liable. First of all, the discriminatory effect can be the result of a plurality of decisions. EU antidiscrimination law regulates, for example, the case in which an instruction is given to discriminate ${ }^{3}$.

The CJEU has not yet clarified whether a parent company can be regarded as jointly and severally liable with the subsidiary for the latter's infringement of EU antidiscrimination law. On the contrary, for the purpose of EU competition law, the CJEU stated that a parent company is regarded as jointly and severally liable with the other legal persons making up a single economic unit for infringements of competition law. «Even if the parent company does not participate directly in the infringement, it exercises, in such a case, a decisive influence over the subsidiaries which have participated in it» ${ }^{4}$.

It must be underlined that a (juridical or natural) person can be liable for discrimination, not only in cases in which it has actively exercised power, but even in cases in which it has illegally tolerated an act of discrimination. An omission can therefore represent an act of discrimination when the person responsible has the duty to prevent it from happening. For example, a temporary work agency can be deemed to be liable for discrimination against

1 M. Barbera, Discriminazioni ed eguaglianza nel rapporto di lavoro, Giuffré, Milan, 1991, p. 51.

2 CJEU, 9 October 2001, C-379/99, Menauer, par. 29 and 30.

3 Art. 2, par. 4 Directive 2000/43/EC; art. 2, par. 4; Directive 2000/78/EC; art. 2, par. 2 Directive 2006/54/EC.

4 CJEU, 10 September 2009, C-97/08, Akzo Nobel NV, par. 77. 
temporary agency workers resulting from the practices adopted by a user undertaking since, in its role as the employer of the temporary agency workers, it has a «duty to ensure the safety and health of workers in every aspect related to the work ${ }^{5}$.

Based on this conceptual framework ${ }^{6}$, the paper investigates if and when a European Company (i.e. a company that has its headquarter or a unit in Europe) can be sue for acts of discrimination caused by its subsidiaries, suppliers or subcontractors inside or outside the EU territory. For this purpose, we first investigate the content of the enterprise's duties to prevent violations of human rights by its subsidiaries, suppliers or subcontractors, established at international, European and national level. Then, we demonstrate how the interconnection between these duties and EU antidiscrimination law can be helpful to enforce non-legally binding duties of care and to guarantee victims of discrimination effective remedies.

\section{I - INTERNATIONAL LAW ON MNE'S DUTY TO RESPECT HUMAN RIGHTS AND DUE DILIGENCE}

\section{A - INTERNATIONAL LAW}

According to the Guiding Principles on Business and Human Rights: Implementing the United Nations «Protect, Respect and Remedy» Framework, enterprises should "avoid causing or contributing to adverse human rights impacts through their own activities» ${ }^{7}$ and «prevent or mitigate adverse human rights impacts that are directly linked to their operations, products or services by their business relationships, even if they have not contributed to those impacts» (principle $\left.{ }^{0} 13\right)^{8}$. The term «business relationship» «includes relationships with business partners, entities in the supply chain and any other non-State or State entities directly linked to its business operations, products or services»?.

Similar duties have been introduced in the 2011 revision of the OECD Guidelines that extend these duties to all matters covered by the Guidelines ${ }^{10}$. Enterprises should also carry out a human rights due diligence process, "to identify, prevent, mitigate and account for

5 Art. 5, par. 1 Directive 89/391/EEC.

6 See S. Borelli, «Principles of Non-Discrimination in Complex Economic Organisations», in Employment Relations and Transformation of the Enterprise in the Global Economy, eds. E. Ales, F. Basenghi, W. Bromwich e I. Senatori, Giappichelli, 2015, p. 3.

7 This duty includes also enterprise's activities in the supply chain (OECD Guidelines, Commentary on General Policies, § 17, p. 24).

8 The UN Guiding principles apply to all States and to all business enterprises, both transnational and others, regardless of their size, location, ownership and structure. Among the human rights that business enterprises must respect are included the rights guaranteed by the eight ILO core conventions as set out in ILO Declaration on Fundamental Principles and Rights at Work (principle $\left.n^{\circ} 12\right)$. Convention $n^{\circ} 111$ concerning discrimination in respect of employment and occupation and the Equal Remuneration Convention ( $n^{\circ} 100$ ) appear among the eight ILO core conventions.

9 OECD Guidelines, Commentary on General Policies, § 14 and Commentary on Human Rights, $\S 43 ;$ Guiding Principles on Business and Human Rights: Implementing the United Nations «Protect, Respect and Remedy» Framework, Commentary on Principle n 13, p. 14.

10 II. General Policies, § 11 and 12, p. 20; on human rights see IV. Human Rights, §2 and 3. 
how they address their impacts on human rights» ${ }^{11}$. The due diligence process "should cover adverse human rights impacts that the business enterprise may cause or contribute to through its own activities, or which may be directly linked to its operations, products or services by its business relationships» ${ }^{12}$.

As clarified by the UN Principles, actions that shall be taken vary according to the degree of the enterprise's leverage ${ }^{13}$. "Leverage is considered to exist where the enterprise has the ability to effect change in the wrongful practices of an entity that causes a harm» ${ }^{14}$.

If an enterprise identifies a risk of contributing to an adverse impact, «it should take the necessary steps to cease or prevent its contribution and use its leverage to mitigate any remaining impacts to the greatest extent possible» ${ }^{15}$. Note that an enterprise may contribute to adverse human rights impacts caused by another party when it benefits «from an abuse committed by that party» ${ }^{16}$.

When an enterprise has not contributed to an adverse impact but the adverse impact is directly linked to its operations, products or services by a business relationship, it should use «its leverage to influence the entity causing the adverse impact to prevent or mitigate that impact» ${ }^{17}$.

Similar duties to respect human rights and to carry out due diligence have been introduced in the 2017 revision of the ILO Tripartite Declaration of Principles concerning Multinational Enterprises and Social Policy that refers them to MNEs ${ }^{18}$. The term MNEs is used in the ILO Declaration «to designate the various entities (parent companies or local entities or both or the organization as a whole) according to the distribution of responsibilities among them, in the expectation that they will cooperate and provide assistance to one another as necessary to facilitate observance of the principles laid down» in the ILO Declaration ${ }^{19}$. The ILO Declaration mentions as well that «the degree of autonomy

11 UN Principles, principle n 15, b ; OECD Guidelines, II. General Policies, § 10, p.20 that extend the due diligence to all matters covered by the Guidelines, and IV. Human Rights, $§ 5$.

12 UN Principles, principle $n^{\circ} 17$.

13 UN Principles, principle $n^{\circ} 19$.

14 UN Principles, Commentary on principle $n^{\circ} 19$, p. 18; OECD Guidelines, Commentary on General Policies, § 19 and Commentary on Human Rights, § 42.

15 UN Principles, Commentary on principle n 19; OECD Guidelines, Commentary on General Policies, $\S 19$ and Commentary on Human Rights, § 42 " 'contributing to' an adverse impact should be interpreted as a substantial contribution, meaning an activity that causes, facilitates or incentivises another entity to cause an adverse impact» (Commentary on General Policies, § 14, p. 23).

16 UN Principles, Commentary on principle ${ }^{\circ}{ }^{17}$. M.C. Caillet, Le devoir de vigilance et les relations d'affaires : vers une responsabilité collective ?, in I. Daugareilh, La responsabilité sociale de l'entreprise, vecteur d'un droit de la mondialisation?, Bruylant, 2017, p. 515.

17 OECD Guidelines, Commentary on General Policies, § 20, p. 24; UN Principles, Commentary on principle $\mathrm{n}^{\circ} 19$ « Appropriate responses with regard to the business relationship may include continuation of the relationship with a supplier throughout the course of risk mitigation efforts; temporary suspension of the relationship while pursuing on going risk mitigation; or, as a last resort, disengagement with the supplier either after failed attempts at mitigation, or where the enterprise deems mitigation not feasible, or because of the severity of the adverse impact» (OECD Guidelines, Commentary to Guiding Principles, § 22, p. 25).

18 General Policies, § 10, c) and d.

19 Aim and scope, §6. 
of entities within multinational enterprises in relation to each other varies widely from one such enterprise to another, depending on the nature of the links between such entities and their fields of activity and having regard to the great diversity in the form of ownership, in the size, in the nature and location of the operations of the enterprises concerned $\rangle^{20}$. Consequently, when a subsidiary violates human rights and has no (or very low) autonomy, this violation shall be ascribed to the parent company. Moreover, all duties regulated by the ILO Declaration (included equality of opportunity and treatment) are assigned to MNEs. This means that the parent company is co-obliged with the subsidiaries to respect these duties and it is jointly responsible of any infringement, except when the subsidiary acted autonomously.

According to the OECD Guidelinesfor Multinational Enterprises, MNEs «usually comprise companies or other entities established in more than one country and so linked that they may coordinate their operations in various ways. While one or more of these entities may be able to exercise a significant influence over the activities of others, their degree of autonomy within the enterprise may vary widely from one multinational enterprise to another ${ }^{21}$. The OECD Guidelines are addressed to all the entities within the MNE that are expected to cooperate and to assist one another to facilitate observance of the Guidelines, «according to the actual distribution of responsibilities among them $»^{22}$ (I. Concepts and Principles, $\S 4$, p. 17). The OECD Guidelines require as well parent companies to ensure «the strategic guidance of the enterprise, the effective monitoring of management» (Commentary on General Policies, § 8, p. 22). Compliance and control systems should extend where possible to subsidiaries. Finally, «the board's monitoring of governance includes continuous review of internal structures to ensure clear lines of management accountability throughout the group» (Commentary on General Policies, § 9, p. 22).

A due diligence process (i.e. «a process to identify the actual and potential negative social, environmental and economic impacts of an organization's decisions and activities, with the aim of avoiding and mitigating those impacts» throughout the enterprise's sphere of influence) is also enlisted among the issues for social responsibility improvement by the ISO $26000^{23}$. The ISO 26000 refers to the enterprise's sphere of influence, i.e. «the range of relationships through which the organization has the ability to affect the decisions or activities of others - that is, its owners, customers, workers, suppliers, etc. ${ }^{24}$.

20 Aim and scope, § 6. «On influence and control that lead firms exert over the operations of their suppliers and subcontractors see ILO, Decent work in global supply chains, Report IV, International Labour Conference, session 105 ${ }^{\text {th }}, 2016$.

21 I. Concepts and Principles, § 4, p. 17.

222010 Clause 7.3.1.

23 See I. Daugareilh, «L'ISO à l'assaut du social : risques et limites d'un exercice de normalisation sociale», in I. Daugareilh (ed.), Responsabilité sociale de l'entreprise transnationale et globalisation de l'économie, Bruylant, Bruxelles, 2010, p. 563.

24 ISO 26000: 2010 Clause 2.18. 
All the sources here considered are non-legally binding documents, i.e. their observance by enterprises is voluntary and not legally enforceable. Indeed, currently an international legally binding instrument to regulate the activities of transnational corporations and other business enterprises does not exist ${ }^{25}$.

\section{B - Due Diligence obligations at European level}

At the European level, Directive 2014/95/EU has introduced for «large undertakings which are public-interest entities» with more than 500 employees and for "public-interest entities which are parent undertakings of a large group» with more than 500 employees, the duty to publish a non-financial statement on the undertaking's/group's development, performance, position and impact of its activity on «environmental, social and employee matters, respect for human rights, anti-corruption and bribery matters ${ }^{26}$. The statement shall include both "a description of the policies pursued by the undertaking [or by the group] in relation to those matters, including due diligence processes implemented $»^{27}$ and «the principal risks related to those matters linked to the undertaking's [or to the group's] operations including, where relevant and proportionate, its business relationships, products or services which are likely to cause adverse impacts in those areas, and how the undertaking [or the group] manages those risks ${ }^{28}$. The due diligence process should identify, prevent and mitigate existing and potential adverse impacts that «may stem from the undertaking's own activities or may be linked to its operations, and, where relevant and proportionate, its products, services and business relationships, including its supply and subcontracting chains» (whereas $\mathrm{n}^{\circ} 8$ ). In providing this information, the undertaking may rely on international frameworks such as the UN Principles, the OECD Guidelines, the ILO Declaration or the ISO $26000^{29}$.

25 In 2014, the Human Rights Council of the UN established an open-ended intergovernmental working group on transnational corporations and other business enterprises with respect to human rights. Many European Member States (included Austria, France, Germany and Italy) and US voted against this decision. In 2016, the European Parliament invited Member States to support the UN initiative (Resolution of 25.10.2016 on corporate liability for serious human rights abuses in third countries). See J. Martens and K. Seitz, The Struggle for a UN Treaty Towards global regulation on human rights and business, Global Policy Forum and Rosa Stiftung-New York Office, Foundation, 2016; B. Faracik, Implementation of the UN Guiding Principles on Business and Human Rights, study for the European Parliament's Subcommittee on Human Rights (DROI), 2017, p. 18.

26 Articles 19a and 29a, § 1 Directive 2013/34/EU.

27 «As regards social and employee-related matters, the information provided in the statement may concern the actions taken to ensure gender equality, implementation of fundamental conventions of the International Labour Organisation, working conditions, social dialogue, respect for the right of workers to be informed and consulted, respect for trade union rights, health and safety at work and the dialogue with local communities, and/or the actions taken to ensure the protection and the development of those communities» (whereas $\mathrm{n}^{\circ} 7$ ).

28 Art. 19a and 29a, § 1 Directive 2013/34/EU.

29 Whereas $\mathrm{n}^{\circ} 9$ and Commission's Communication, Guidelines on non-financial reporting (methodology for reporting non-financial information), 2017/C 215/01, § 4.2. 
A due diligence system is regulated as well by the Timber Regulation ${ }^{30}$. In this context, the due diligence requires an operator to undertake a risk management exercise so as to minimise the risk of placing illegally harvested timber, or timber products containing illegally harvested timber, on the EU market.

An EU conflict minerals regulation aiming to introduce due diligence obligations for EU companies dealing with certain minerals to mitigate the risk of human rights abuses along the supply chain was adopted in 2017 (Reg. 2017/821). EU importers of minerals and metals shall respect due diligence throughout their supply chain consistently with the standards set out in the OECD Due Diligence Guidance for Responsible Supply Chains of Minerals from Conflict-Affected and High-Risk Areas (Article 4). Risk management measures that shall be adopted to prevent or mitigate adverse impacts, depend on the enterprise's «ability to influence, and where necessary take steps to exert pressure on suppliers who can most effectively prevent or mitigate the identified risk» (Article 5, § 1, let. b) (ii).

\section{II - DUE DILIGENCE OBLIGATIONS AT NATIONAL LEVEL}

At national level, we should mention first the recent French Law on the devoir de vigilance des sociétés mères et des entreprises donneuses d'ordre ${ }^{31}$. The law obliges any company established in France that employs at least 5000 employees within the company head office and its direct and indirect subsidiaries, whose head office is located on French territory, or at least 10000 employees within the company and its direct and indirect subsidiaries, whose head office is located on French territory or abroad, to establish and implement a vigilance plan $^{32}$. The vigilance plan must include appropriate measures to identify the risks and prevent serious infringements to human rights and fundamental freedoms, health and safety and environment, resulting from company's activities and those of the companies it controls directly or indirectly, as well as from activities of subcontractors and suppliers with whom it maintains an established business relationship ${ }^{33}$. In case of infringement of the duty of care, the company can be held liable and shall compensate for damages that proper fulfilment of the obligation would have avoided ${ }^{34}$.

30 Regulation (EU) No 995/2010.

31 Loi n 2017-399. N. Cuzacq, Le devoir de vigilance des sociétés mères et des entreprises donneuses d'ordre, Dalloz, Paris, 2015 ; R.C. Drouin, " Le développement du contentieux à l'encontre des entreprises transnationales : quel rôle pour le devoir de vigilance? " Droit Social, 2016, p. 246 ; O. Favereau, «Le devoir de vigilance dans les groupes et réseaux de sociétés. Sur la proposition de loi adoptée par l'Assemblée nationale le 30 mars 2015», RDT, 2015, p. 446-450 ; C. Hannoun, Pour un dispositif de vigilance mesuré et efficace, RDT, 2014, p. 441-444; C. Hannoun, Proposition pour un devoir de vigilance des sociétés mères, in Mélanges offertes à M. Germain, Dalloz, Paris, 2014, p. 342; A. Lyon-Caen and T. Sachs, "The responsability of multinational enterprises. A constitutionalization process in action », in J.P. Robé, A. Lyon-Caen and S. Vernac (eds.), Multinationals and the constitutionalization of the world power system, Routledge, New York, 2016, p. 204 ; M. A. Moreau, "Le rôle des juges face à l'exigence d'une réglementation sociale transnationale», Droit social, $\mathrm{n}^{\circ} 3$, p. 200.; S. Schiller, «Encourager plutôt que contraindre », RDT, 2014, p. 444-446; Sachs T., « La loi sur le devoir de vigilance des sociétés mères et sociétés donneuses d'ordre : les ingrédients d'une corégulation $», R D T 2017$, p. 380 ; and the essays published in Droit social, $n^{\circ}$ 10/2017.

32 Article L. 225-102-4 of the French Commercial Code.

33 For details on the content of the plan see Article L. 225-102-4, § 4 of the French Commercial Code.

34 Article 225-102-5. The French Constitutional Council removed the $€ 10$ to $€ 30$ million civil penalty for breaches of the duty of care (décision $n^{\circ}$ 2017-750). 
A due diligence process is regulated also in the UK Modern Slavery Act 2015 35 . This law obliges any commercial organisation that carry on a business (or part of a business) in the UK, to prepare a slavery and human trafficking statement (i.e. a statement of the steps the organisation has taken to ensure that slavery and human trafficking is not taking place in any of its supply chains, and in any part of its own business) that may include its due diligence processes in relation to slavery and human trafficking in its business and supply chains $^{36}(5)$. The English case law establishes as well that a parent company can, in certain circumstances, owe a duty of care in the tort of negligence to employees of a subsidiary ${ }^{37}$. The duty of care of the parent company is based on three conditions (the so-called Caparo three-stage test for negligence) $)^{38}$ :

1) the damage was foreseeable;

2) there was sufficient proximity between parties;

3) and it was fair, just and reasonable for a duty of care to exist.

If the three conditions are fulfilled, the parent company is found to be 'directly' liable. In Chandlerv Cape plc [2012] EWCA Civ 525, the Court of Appeal ruled that the parent company was liable for failing in its duty of care with respect to employees of a subsidiary suffering from industrial diseases relating to asbestos exposure, because it knew or should have realised that working conditions at the subsidiary were unsafe, and it should have foreseen the risk of damages (foreseeability). Moreover, the parent company had sufficient control over the subsidiary, since it had taken health and safety actions applicable to all employees of the corporate group, including its subsidiaries' employees (proximity between the claimant and the company). Lastly, the fact that asbestos exposure is recognised as a major health risk provided fair, reasonable justification for imposing the duty of care ${ }^{39}$.

Finally, we should mention the Resolution concerning decent work in global supply chains adopted by the General Conference of the ILO in its $105^{\text {th }}$ session (2016). In this document, States are recommended to «stimulate transparency and encourage, where appropriate, require, by various means, that enterprises report on due diligence within their supply chains to communicate how they address their human rights impacts» ( $\S 16$ (f) and (i); see also the Recommendation of the Committee of Ministers of the Council of Europe on human rights and business, adopted the 2 March 2016, § 20). Similarly,

35 See D. Blackburn, A. Sanders, R. Subasinghe, Supply chains liability: UK report, 2015.

36 MSL 2015, part 6, Article 54.

37 R. Meeran, «Access to Remedy: the United Kingdom Experience of MNC Tort Litigation for Human Rights Violations'» in S. Deva and D. Bilchitz (eds), Human Rights Obligations of Businesses: Beyond the Corporate Responsibility to Respect? (CUP 2013); A. Sanger, "Crossing the corporate veil: the duty of care owed by a parent company to the employees of its subsidiary», CLJ, 2012, n71, p. 478; C. Bright, Le devoir de la société mère dans la jurisprudence anglaise, Droit social, 2017, p. 828.

38 Caparo Industries Plc v Dickman [1990] 2 AC 605 (HL).

39 According to Arden LJ, the circumstances in which the law may impose on a parent company responsibility for the health and safety of its subsidiary's employees «include a situation where, as in the present case, (1) the businesses of the parent and subsidiary are in a relevant respect the same; (2) the parent has, or ought to have, superior knowledge on some relevant aspect of health and safety in the particular industry; (3) the subsidiary's system of work is unsafe as the parent company knew, or ought to have known; and (4) the parent knew or ought to have foreseen that the subsidiary or its employees would rely on its using that superior knowledge for the employees' protection» (Chandlerv Cape plc [2012] EWCA Civ 525, [80]). 
OECD Guidelines commit countries adhering to the OECD Declaration on International Investment and Multinational Enterprises to promote the application of the Guidelines by all companies with headquarters in their countries wherever they operate, as well as by companies operating within their territory. As stated by the Report of the United Nations High Commissioner for Human Rights Improving accountability and access to remedy for victims of business-related human rights abuse, «ensuring the legal accountability of business enterprises and access to effective remedy for persons affected by such abuses is a vital part of a State's duty to protect against business-related human rights abuse» (§ 1).

\section{DUE DILIGENCE OBLIGATIONS IN COLLECTIVE AGREEMENTS}

A due diligence obligation throughout the supply chain can also be regulated by global framework agreements negotiated between trade unions and multinational companies. Currently, neither international law nor European law regulate these agreements so that generally they are not considered legally binding.

The Accord Danone/UITA sur l'emploi durable et l'accès aux droits signed on 15 March 2016, for example, obliges Danone to encourage the agreement's application by group's suppliers and in activities where Danone participates, according to the duty of care regulated by OECD Guidelines ${ }^{40}$. The Agreement guarantees also equal pay for equal work and non-discriminating working conditions to workers directly employed by Danone, to temporary agency workers and to workers employed by a service provider.

However, the majority of agreements do not refer to a due diligence obligation, but just introduce different types of obligations for the lead company to encourage the respect of workers' rights by other companies involved in their activities. The Global Framework Agreement between H\&M and IndustriALL Global Union and Industrifacket Metall on compliance and implementation of international labour standards at the suppliers of H\&M signed on 9 September 2015, for example, requires H\&M to «use all its possible leverage to ensure that its direct suppliers and their subcontractors producing merchandise/ready made goods sold throughout H\&M group's retail operations respect human and trade union rights in the workplace».

The 2012 GDF Suez Group European Agreement on professional equality between women and men commits the company to ensure that its suppliers and subcontractors comply with the principles of equality between women and men (Article 13). Similarly, the International Framework Agreement between ThyssenKrupp AG, its Group Works Council, IG Metall and IndustriALL Global Union signed in 2015, binds the company to encourage its suppliers to consider fundamental principles and ILO core labour standards in their own company policy (Article 10). However, both agreements do not specify which measures shall be adopted to fulfil these obligations.

40 On Danone GFA 2016 see M. Frapard, " La protection des droits sociaux fondamentaux des travailleurs dans les entreprises transnationales », RDT, 2017, p. 49. 
Finally, we should mention codes of conduct and private compliance initiatives voluntarily engaged by lead companies to monitor compliance with human rights. Notwithstanding the limitations of private voluntary initiatives in effectively identifying and preventing risks ${ }^{41}$, these voluntary mechanisms sometimes entail a duty of care on the supply chain or mention the respect of the UN Guiding Principles, the OECD Guidelines or the ILO Declaration.

\section{DUE DILIGENCE OBLIGATIONS AND LIABILITY FOR DISCRIMINATION}

Having shortly mentioned the different sources of the enterprise's duties to prevent violations of human rights by its subsidiaries, suppliers or subcontractors, we should now verify if and when a European company can be held liable for a discrimination occurred in its supply chain. Premises of our analysis are:

1) the fact that a company in the supply chain discriminated against its workers on a ground forbidden by EU antidiscrimination law (damage);

2) the fact that the lead company has infringed its duty of care on the supply chain (breach of duty);

3) the fact that the duty of care concerns the respect of the principle of nondiscrimination violated by the company in the supply chain;

4) the fact that, having respected the duty of care, the lead company could have prevented or mitigated the supply chain company's discrimination (causal connection between the damage and the breach of duty).

Of course, in a case pending before a court, all these premises must be duly proved and this is often not an easy task. In order to enforce the duty of care, many authors have claimed measures to reverse the burden of proof, i.e. to require lead companies to demonstrate that they took all reasonable steps to prevent the damage or that they were not in control of the activities that caused the harm ${ }^{42}$. Moreover, it has been suggested to introduce a disclosure obligation «which would allow claimants to request the court to order a company-defendant to disclose all details of: the control it exercises over its subsidiaries and contractors;

41 See Human Rights Watch World Report, Without Rules: A Failed Approach to Corporate Accountability, 2013; AFL-ClO, Responsibility Outsourced: Social Audits, Workplace Certification and Twenty Years of Failure to Protect Worker Rights, 2013.

42 J. J. Álvarez Rubio and K. Yiannibas (eds.), Human Rights in Business. Removal of barriers to access to justice in the European union, Routledge, 2017, part IV; Improving access to remedy in the area of business and human rights at the EU level, Opinion of the European Union Agency for Fundamental Rights, 2016, p. 7 and 34; S. Cossare and M.L. Guislain, «Le devoir de vigilance pour les entreprise multinationals, un impératif juridique pour une économie durable», RLDA, 2015, p. 75. Interpreting the recent French Law on the duty of care, C. Hannoun («Le devoir de vigilance des sociétés mères et entreprises donneuses d'ordre après la loi du 27 mars 2017», Droit social, 2017 , p. 816) has suggested to apply to lead companies the jurisprudence on the «présomption d'identification du risque en cas d'alerte»: if the lead company is alerted of certain risks, it has the duty to investigate and to take appropriate measures. 
its general involvement in the management of its subsidiaries and contractors; its control and involvement in the specific case connected to the claim, inasmuch as this information is relevant for assessing the company-defendant's duty of care» ${ }^{43}$.

As clarified in the previous paragraphs, an international or EU legally binding duty of care does not yet exist. Indeed, each regulation can bind different companies (subjective scope), can provide a different definition of business relationship (objective scope), can apply to different human rights, can be legally binding or not. There is however a common element among these duties: the measures that the lead company shall adopt to prevent or reduce the risk of human rights infringement depend on the degree of influence on the companies in its supply chain.

The link between EU antidiscrimination law and the duty of care allows ascribing the discrimination to the lead company: as we pointed out (par. 1), a company is liable for a discrimination that it has the duty to prevent. On the other side, this link solves the problem of the duty of care's lack of enforceability: the violation of the duty of care is a premise of the violation of EU antidiscrimination law. Therefore, soft law provisions are used to ground «la reconnaissance d'obligations découlant de règles de droit dur, contribuant de ce fait à la construction d'un système de régulation mixte» ${ }^{44}$.

Considering the due diligence obligation (even if non legally binding for MNEs) in assessing liability for discrimination would help in enforcing the enterprises' respect of human rights, as requested by the UN Principles ${ }^{45}$, the OECD Guidelines ${ }^{46}$ and the ILO Declaration ${ }^{47}$.

When the duty of care is sourced in a Global Framework Agreement or in a code of conduct, the courts should take into account that the lead company voluntary signed this agreement or adopted the code, engaging in a due diligence process. Consequently, the lead company's violation of the duty of care (even if it is not binding) should be relevant in ascribing the liability for a supply chain company's discrimination.

43 C. van Dam, F. Gregor, Corporate responsibility to respect human rights. Vis-à-vis legal duty of care, in Human Rights in Business. Removal of barriers to access to justice in the European Union. Executive summary, 2017, p. 22.

44 R.C. Drouin, «Le développement du contentieux à l'encontre des entreprises transnationales : quel rôle pour le devoir de vigilance?», Droit Social, 2016, p. 255 ; see also K. Martin-Chenut, " Devoir de vigilance : internormativités et durcissement de la RSE », Droit social, 2017, p. 802.

45 The UN Principles oblige States to «set out clearly the expectation that all business enterprises domiciled in their territory and/or jurisdiction respect human rights throughout their operations» (principle $\mathrm{n}^{\circ} 2$; see also the Recommendation of the Committee of Ministers of the Council of Europe on human rights and business, adopted the 2 March 2016, § 13).

46 The OECD Guidelines require governments to encourage the enterprises operating on their territories to observe the rules here established wherever they operate (see OECD Guidelines, I. Concepts and Principles, § 3).

47 The ILO Declaration prescribes governments to ensure that when business-related human rights abuses occur within their territory and/or jurisdiction any affected worker or workers have access to effective remedy ( $\S 64$ ). National courts, being part of the State organisation, shall fulfil the mentioned State's obligations. 
When a legally binding duty of care exists, the advantage of linking EU antidiscrimination law to the duty of care lies in the possibility to use the enforcement measures regulated by the former (e.g. shift in the burden of proof, collective action, urgency procedure, sanctions), to prove and sanction discriminations occurred in the supply chain.

If the discrimination has been caused by a subsidiary, supplier or subcontractor established in a State different from the one where the lead company is based, it is necessary to decide which court has the jurisdiction and which law is applicable. The disputes concerning EU Member States are regulated by the Brussels I Regulation (Recast) and the Rome II Regulation. The first one prescribes that «persons domiciled in a Member State shall, whatever their nationality, be sued in the courts of that Member State ${ }^{48}$. Alternatively, the defendant company can be sued «in the courts of the place where the harmful event occurred or may occur» ${ }^{49}$. Therefore, the lead company can be sued in the court of the Member State where it is established or in the court of the Member State where the discrimination happened. And here can as well be sued the subsidiary, supplier or subcontractor established in a different Member State ()$^{50}$.

The Rome II Regulation affirms that «the law applicable to a non-contractual obligation arising out of a tort/delict shall be the law of the country in which the damage occurs» (Article 4, § 1 Regulation $n^{\circ}$ 864/2007). Consequently, it should be applied the law of the country where the discrimination took place. However, Article 16 prescribes that the competent court shall apply «the provisions of the law of the forum in a situation where

48 Article 4, § 1 Regulation $n^{\circ} 1215 / 2012$. For the purposes of Regulation $n^{\circ} 1215 / 2012$, «a company or other legal person or association of natural or legal persons is domiciled at the place where it has its: (a) statutory seat; (b) central administration; or (c) principal place of business» (Article 63, $\S$ 1). See O. De Schutter, «La responsabilité des Etats dans le contrôle des sociétés transnationales: vers une convention internationale sur la lutte contre les atteintes aux droits de l'homme commises par les sociétés transnationales», in I. Daugareilh (ed.), Responsabilité sociale de l'entreprise transnationale et globalisation de l'économie, Bruylant 2010, p. 707.

49 Article 7, § 2 Regulation $n^{\circ} 1215 / 2012$. The place where the harmful event occurred covers both the territory of the country where the event giving rise to the damage occurred and the territory of the country where the harmful result takes place (CJEU, 30.11.1976, Case 21/1976).

50 Article 8, § 1 Reg. 1215/2012. The revision of Brussels I Regulation in 2012 did not introduce the forum necessitates. According to the Council of Europe, States «should consider allowing their domestic courts to exercise jurisdiction over civil claims concerning business-related human rights abuses against such a business enterprise, if no other effective forum guaranteeing a fair trial is available (forum necessitatis) and there is a sufficiently close connection to the Member State concerned» (Council of Europe, Recommendation on human rights and business, 2.3.2016, $\S 36)$ See D. Augenstein, N. Jägers, Judicial remedies: the issue of jurisdiction, in Human Rights in Business. Removal of barriers to access to justice in the European Union. Executive summary, 2017, p. 13; Improving access to remedy in the area of business and human rights at the EU level, Opinion of the European Union Agency for Fundamental Rights, 2016, p. 8). Some Member States «uphold jurisdiction of necessity (forum necessitatis) to avoid cases of denial of justice and to guarantee effective judicial protection as outlined in article 6 of the European Convention on Human Rights (ECHR)» (A. Pigrau Solé, M. Álvarez Torné, A. Cardesa-Salzmann, M. Font I Mas, D. Iglesias Márquez, J. Jaria I Manzano, Human rights in business. A practical handbook for civil society organisations and human rights defenders, 2016, p. 42 and p. 68). On forum necessitatis see the French case Comilog: I. Bertrand, Coemploi international : juridiction territorialement compétente, in Revue de droit du travail 2015, p. 203 ; E. Pataut, "Le contentieux collectif des travailleurs face à la mondialisation. Réflexions à partir de l'affaire Comilog », Droit Social, 2016, p. 554. 
they are mandatory irrespective of the law otherwise applicable to the non-contractual obligation». National law implementing EU antidiscrimination law can be listed among the mandatory overriding provisions of the law of the forum, so as national law on duty of care ${ }^{51}$. Indeed, Article 16 refers to provisions of fundamental importance as the ones adopted to implement ILO Core Labour Standards, EU fundamental rights and principles, and provisions whose aim has been internationally recognised ${ }^{52}$.

Another possibility is offered by Article 4, $\S 3$ of the Rome II Regulation according to which, if the tort is manifestly more closely connected with a country other than the one in which the damage occurred, the law of that other country shall apply. «A manifestly closer connection with another country might be based in particular on a preexisting relationship between the parties» (Article 4, § 3), as it is the case between lead company and subsidiaries, suppliers or subcontractors ${ }^{53}$.

Both the interpretations are consistent with the obligation of States, under the UN Guiding Principles (principle $\mathrm{n}^{\circ} 25$ ), to consider ways to reduce legal, practical and other relevant barriers that could lead to a denial of access to remedy.

Therefore, when the discrimination has occurred in an EU Member States, the lead company can be sued in the court where it is domiciled (Article 4, §1 Reg. 1215/2012). This court has to apply the law of the State where the damage occurred (Article 4, §1 Reg. 864/2007). Being antidiscrimination law harmonised at EU level, any competent court shall apply national law in a way consistent with the above-mentioned principles, i.e. shall declare the lead company liable for discriminations that it could have prevented respecting its duty of care.

When the lead company is established in an EU Member State and the discrimination happened outside the EU territory, it can be sued in the court where it is domiciled ${ }^{54}$ and this court should consider EU antidiscrimination law as mandatory provisions of the lex fori. In this case as well, a lead company established in an EU Member States should be held liable for discriminations occurred in its supply chain that it could have prevented respecting its duty of care.

51 See J. J. Álvarez Rubio and K. Yiannibas (eds.), Human Rights in Business. Removal of Barriers to Access to Justice in the European Union, Routledge, 2017, part II; O. De Schutter, "Le contrôle du respect des droits de l'homme par les sociétés transnationales : le rôle de l'État d'origine ", in H. Miur Watt, M.A. Moreau, P. Rodière, Justice et mondialisation en droit du travail. Du rôle du juge aux conflits alternatifs, Dalloz, Paris, 2010.

52 M. Saage-Maaß, Holding Companies Accountable. Lessons from transnational human rights litigation, 2014, p. 22

(https://www.brot-fuer-die-welt.de/fileadmin/mediapool/2 Downloads/Fachinformationen/ Sonstiges/Brochure_HoldingCompaniesAccountable_Einzelseiten.pdf).

53 E. Pataut, "Le devoir de vigilance. Aspects de droit international privé », Droit Social, 2017, p. 839.

54 On the possibility of third-country victims of human rights abuses committed by EU-based multinational companies to sue them in EU Member State courts see J. J. Álvarez Rubio and K. Yiannibas (eds.), Human Rights in Business. Removal of Barriers to Access to Justice in the European Union, Routledge, 2017, part I. 


\section{DISCRIMINATION AND DUTY OF CARE OF EMN}

\section{Conclusion}

EU Principles of non-discrimination shall be considered among the techniques that allow regulating the exercise of power beyond the contract of employment and in complex organisations: any person that has caused or illegally tolerated a discrimination shall be liable for it. Therefore, a company can be held liable for a discrimination caused by a different company in its supply chain whenever the fulfilment of its duty of care could have prevented the discrimination to happen.

The link between EU antidiscrimination law and the duty of care allows enforcing non-legally binding duty of care: the violation of the duty of care becomes part of the antidiscrimination judgement. Moreover, enforcement measures regulated by EU antidiscrimination law can facilitate collecting evidences and acting against human rights violations in the supply chain. Consequently, the interconnected between soft law and hard law strengthens the obligation, for the MNEs, to respect of human rights throughout their supply chain. The result is the re-allocation of responsibility within the complex organisations: a lead company is jointly liable of any violation caused by its subsidiaries, suppliers or subcontractors, when it has the power to influence risky conducts throughout its business relationships and it profits from the activities in the supply chain.

\section{SILVIA BORELLI \\ Professor of Labor Law, University of Ferrara (Italy)}

Research subjects: European Law, Anti-discrimination Law, Labor Law, Complex Economic Organizations.

\section{Publications:}

S. Borelli, J.M. Serrano García, « El necesario reconocimiento de los derechos sindicales a los trabajadores de la economia digital $»$, Revista de Derecho Social, n 80/2018.

S. Borelli, «Tecniche di regolazione delle organizzazioni complesse e disciplina lavoristica», Lavoro e diritto, $n^{\circ} 1 / 2014$, p. 23-35. 